УДК 342.951:351

DOI https://doi.org/10.32838/TNU-2707-0581/2020.5/15

\title{
Смичок С.M.
}

Національний юридичний університет імені Ярослава Мудрого

\section{СУДОВА ДОКТРИНА РОЗУМНОЇ ЕКОНОМІЧНОЇ ПРИЧИНИ}

Автором було розкрито основи проблематики формування судової доктрини розумної економічної причини (ділової мети). Акиентовано увагу на нормативних підходах до формулювання концепції розумної економічної причини (ділової мети) та судово-доктринальних концептів визначення ї̈ змістовного наповнення. Досліджувана доктрина ділової мети отримала свій первинний розвиток саме в судовій практиці. У судовій практиці підкреслювався взаємозумовлюючий характер доктрини ділової мети та доктрини податкових вигод. На підставі ивого було виділено й описано характерні особливості взаємозалежності судової доктрини ділової мети з іншими судовими доктринами: доктриною податкових вигод, доктриною добросовісності платника податків. Як приклад, судом було запропоновано альтернативне означення податкових вигод - податкові преференції. При цьомусуд у своєму ріменні дійшов висновку, що отримання платником податків податкових вигод у вигляді витрат (в аспекті податку на прибуток) або ж податкового кредиту (в аспекті ПдВ) не є допустимим без наявності розумної економічної причини в операчіях, які й зумовлюють такі вигоди. Піддано конструктивній критиці нормативне формулювання поняття «економічний ефект». Як відмічає суд, економічний ефект є наявним тоді, коли операція спрямована на приріст (збереження) активів платника податків або ж сприяє створенню умов для такого приросту (збереження) в майбутньому. На основі вивчення практики судів адміністративної юрисдикиії встановлено фрагментарність підходів до формулювання судової доктрини розумної економічної причини (ділової мети). Доктрина розумної економічної причини потребує иілком логічного нормативного доопрацювання. Встановлено, щуо судова практика в цій проблемі має стати основою для такої нормативної модернізаиії. У даному випадку прослідковується конструктивний взаємовплив судової та законодавчої гілок влади. Судова гілка влади в аспекті формування судової доктрини розумної економічної доктрини стала своєрідним першопрохідием.

Ключові слова: податкове право, доктрина податкового права, судові доктрини, розумна економічна причина, ділова мета, економічний ефект, судова практика, податкові вигоди.

Постановка проблеми. У статті проаналізовано проблематику, пов'язану з формуванням судових доктрин. Саме судові доктрини дозволяють заповнити прогалини у праві, подолати правові колізії тощо. Водночас судові доктрини направлені не тільки на нівелювання негативних явищ у праві (колізій та прогалин), але й на поступальний розвиток правових положень. Судові доктрини формують положення, які доповнюють чинне нормативне регулювання і тим самим розвивають його. Не $\epsilon$ виключенням у даному випадку концепція розумної економічної причини (ділової мети), яка вже давно отримала своє лаконічне нормативне закріплення в межах податкового законодавства, надалі була концептуально сформована на рівні судової доктрини, а в останній час зазнала спроб законодавчої концептуалізації. Важливим залишається той аспект, що первинно будучи оціночним поняттям, розумна економічна причина (ділова мета) так і залишилася оціночним поняттям.
Аналіз останніх досліджень і публікацій. Доктрина податкового права, судова доктрина як частина родового поняття «доктрина податкового права», а також підстави та механізми їх виникнення, досліджувалися i досліджуються такими вченими галузі фінансового права, як: М. П. Кучерявенко, Т. О. Коломоєць, П. С. Лютіков, О. Г. Глухий, Т. А. Латковська, Р. Ф. Ханова, В. В. Хохуляк та ін.

Постановка завдання. Метою статті є з'ясування природи доктрини розумної економічної причини (ділової мети), аналіз еволюції нормативно-правового регулювання цього питання, а також узагальнення судової практики, яка стосується формування зазначеної судової доктрини.

Виклад основного матеріалу дослідження. Із загальнотеоретичного підходу під оціночними поняттям потрібно розуміти нормативно зафіксований припис, який визначає найбільш уза- 
гальнені ознаки та властивості явищ, предметів, дій або процесів, які отримують свою конкретизацію в рамках окремо взятих актів правозастосування $[2$, с. 8$]$. У податковому праві оціночні поняття також $є$ наявними. Так, Т. О. Коломоєць, П. С. Лютіков і О. Г. Глухий влучно відмічають, що належність застосування податково-правового оціночного поняття на практиці залежить від доповненості його змісту за посередництвом тлумачення, що фактично забезпечує реконструкцію змістовного наповнення такого оціночного поняття [3, с. 19]. Щодо оціночних понять у податковому праві, то потрібно зауважити, що вони можуть отримувати свою конкретизацію або ж спроби конкретизації в:

a) нормативному порядку;

б) судовій практиці.

Окремо потрібно зазначити про конкретизацію оціночних понять у правотлумачній практиці контролюючих органів та в підзаконних нормативно-правових актах Міністерства фінансів України і контролюючих органів, що отримує свою фіксацію в підзаконних актах податкового законодавства, листах, узагальнюючих та індивідуальних податкових консультаціях. Розглядаючи проблематику концептуалізації поняття «розумна економічна причина» (ділова мета), ми проаналізуємо нормативні підходи до уточнення даного оціночного поняття та судово-доктринальні концепти визначення його змістовного наповнення.

Насамперед потрібно розглянути законодавчі формулювання розумної економічної причини (ділової мети). Дефініція поняття «розумна економічна причина (ділова мета)» отримує своє нормативне закріплення в Податковому кодексі України (далі - ПКУ). Так, розумна економічна причина (ділова мета) - це причина, яка може бути наявна лише за умови, що платник податків має намір одержати економічний ефект у результаті господарської діяльності (абз. 1 пп. 14.1.231 п. 14.1 ст. 14 ПКУ) [4]. 3 відповідного визначення випливає декілька принципових аспектів. По-перше, 3 даної дефініції вбачається формально-юридична дихотомія відповідного терміна, що проявляється в наявності двох змістовно тотожних нормативних терміносполук - «розумна економічна причина» та «ділова мета». По-друге, наявність самої ділової мети напряму залежить від економічного ефекту, який досягається через проваджувану суб'єктом господарювання діяльність. Без наявності позитивного економічного ефекту ділова мета проваджуваних операцій за логікою нормотворця відсутня.
Потрібно зауважити, що до недавнього часу в рамках податкового законодавства було відсутнє пояснення, в чому ж саме полягає «економічний ефект». Подолати такого роду невизначеність був покликаний Закон України «Про внесення змін до Податкового кодексу України щодо вдосконалення адміністрування податків, усунення технічних та логічних неузгодженостей у податковому законодавстві» від 16.01.2020 p. № 466-IX (далі - Закон № 466) [1].

Відповідно до положень абз. 2 пп. 14.1.231 п. 14.1 ст. 14 ПКУ економічний ефект передбачає приріст (збереження) активів платника податків та/або їх вартості, а так само створення умов для такого приросту (збереження) у майбутньому. Таким чином, ми повинні резюмувати, що позитивний економічний ефект, який є необхідною умовою наявності ділової мети, має місце в таких випадках:

a) якщо господарські операції платника податків мають своїм наслідком збереження/приріст його активів;

б) якщо господарські операції платника податків створюють умови для збереження/приросту його активів у майбутньому.

Нібито конкретизація умов наявності ділової мети на нормативному рівні і має місце, однак вона все одно не привносить однозначності в правозастосовну практику. Комплексність господарської діяльності не можна описати односкладними компонентами. На основі яких критеріїв повинна трактуватися окрема господарська операція чи низка таких операцій, виходячи з вимог економічного ефекту? Як бути у тих випадках, коли операція здійснюється на нібито невигідних для постачальника цінах через те, що надалі він взагалі не зможе здійснити реалізацію відповідних товарів? Фактично ми доходимо висновку, що в кожному конкретному випадку наявність економічного ефекту може зводитися до оціночних суджень контролюючого органу.

Такий стан справ у сфері оподаткування не $\epsilon$ позитивним аспектом. Будь-яка розширена дискреція контролюючого органу - це потенційні ризики для платника податків. Сфера оподаткування завжди характеризувалася підвищеною мірою формалізації. Оціночні поняття, до яких відноситься в тому числі й термін «розумна економічна причина» (ділова мета), об'єктивно потребували нормативної конкретизації. Проте в нашому випадку оціночне поняття «розумна економічна причина (ділова мета)» було конкретизовано за посередництвом не менш 
оціночного поняття «економічний ефект». Конкретизація одного оціночного поняття через інше оціночне поняття не відповідає вимогам правової визначеності. Такий підхід законодавця до нормативного конструювання породжує цілий комплекс проблем, вирішення яких можливо тільки у правозастосовчій практиці, зокрема практиці Верховного Суду.

У контексті дослідження нормативних конструкцій розумної економічної причини потрібно також розглянути новели податкового законодавства, які були внесені Законом № 466 та які мають своїм завданням перешкоджати функціонуванню так званих моделей «агресивного» податкового планування із залученням нерезидентів. Йдеться про приписи абз. 3-5 пп. 14.1.231 п. 14.1 ст. 14 ПКУ, де зазначається, що для цілей оподаткування вважається, що операція, здійснена 3 нерезидентами, не має розумної економічної причини (ділової мети), зокрема, але не виключно, якщо:

1) головною ціллю або однією з головних цілей операції та/або іiі результатом $є$ несплата (неповна сплата) суми податків та/або зменшення обсягу оподатковуваного прибутку платника податків;

2) у зіставних умовах особа не була б готова придбати (продати) такі роботи (послуги), нематеріальні активи, інші предмети господарських операцій, відмінні від товарів, у непов'язаних осіб [4].

Відповідні приписи мають своїм завданням перешкоджати моделям оптимізації оподаткування, які застосовуються платниками податків. При цьому такі нормативні приписи також позбавлені належної міри конкретики й містять низку понять оціночного характеру. Так, не до кінця зрозумілим залишається питання: на основі яких критеріїв визначатиметься «головна ціль» або ж «одна із головних цілей» провадження господарської операції? Відповідні формулювання дають значні можливості для зловживання з боку контролюючих органів. Які механізми та критерії визначення головної цілі або ж їі (цілі) наближення до головної не визначені в рамках актів чинного законодавства? Зазвичай модель взаємодії «резидент - нерезидент» застосовується транснаціональними корпораціями, а такі нормативні положення, позбавлені будь-якої прогнозованості в аспекті їх подальшого правозастосування, безумовно, применшують інвестиційну привабливість України.

Також викликає запитання доцільність застосування у рамках даної норми об'єктивно визначеної терміносполуки «несплата (неповна сплата) суми податків». Несплата або ж неповна сплата податків має місце тільки в тому випадку, коли платник невірно визначив належні йому грошові зобов'язання 3 конкретного податку чи збору і не виконав свій обов'язок 3 їх сплати. У випадку ж із приписами пп. 14.1.231 п. 14.1 ст. 14 ПКУ відповідна терміносполука не була суб'єктивно зумовленого характеру, адже прирівнює фактично легальну оптимізацію податкових зобов'язань до несплати (неповної) сплати податків та зборів.

Також дискусійною є терміносполука «зіставні умови». Вона, до речі, є новелою Закону № 466. Поняття «зіставність», «зіставні операції» $\epsilon$ термінами, які застосовуються в рамках інституту трансфертного ціноутворення. При цьому поняття «зіставні умови» $є$ новим для податкового законодавства. Саме ж визначення зіставності умов також за логікою нормотворця повинно покладатися на суб'єкта правозастосування, яким $є$ контролюючий орган. Що ж стосується «готовності» вчинити операцію, про яку йдеться в абз. 5 пп. 14.1.231 п. 14.1 ст. 14 ПКУ, то вона у своєму чистому вираженні є суб'єктивною, вольовою категорією, яка не може бути розкрита за посередництвом чітко сформованих нормативно закріплених критеріїв.

Відповідно, ми повинні констатувати, що нормативно закріплені конструкції розумної економічної причини (ділової мети) основуються на оціночних поняттях. Новели, запроваджувані Законом № 466, тільки поглибили проблему оціночного характеру відповідного поняття. Системність помилки нормотворця полягає в тому, що оціночне поняття «розумна економічна причина» (ділова мета) конкретизується за посередництвом застосування таких же само оціночних понять. Така ситуація породжує «замкнуте коло» оціночних понять, що не спрощує, а тільки ускладнює правозастосування.

Крім цього, наявність цілої низки оціночних понять нівелює стандарти правової визначеності, яка $є$ елементом принципу верховенства права. Важливо відмітити той аспект, що застосування оціночних понять у податковому праві $\epsilon$ допустимим, однак воно повинно бути зведеним до мінімуму. Що, однак, є абсолютно недопустимим, то це пояснення оціночних понять за посередництвом цілої низки інших оціночних понять. У зв'язку із цим $є$ доцільним доопрацювання нормативних положень, які визначають правовий механізм встановлення розумної економічної причини (ділової мети). Такого роду уточнення потрібно робити саме на рівні закону, 
адже якщо таке уточнення буде здійснено на підзаконному рівні (Міністерством фінансів України чи Державною податковою службою України), то існуватимуть потенційні ризики необгрунтованої «фіскалізації» критеріїв визначення розумної економічної причини (ділової мети).

Далі розглянемо концептуалізацію розумної економічної причини (ділової мети) у рамках судової практики. Потрібно зауважити, що первинно розвиток концепції розумної економічної причини (ділової мети) отримав свій вияв саме у практиці вищих судових інстанцій. Так, звернемо увагу на правову позицію, що була викладена в Постанові Верховного Суду в складі колегії суддів Касаційного адміністративного суду від 06.06.2018 р. (справа № 804/7948/16), де зазначалося таке: «Мета отримання доходу як кваліфікуюча ознака господарської діяльності кореспондує з вимогою щодо наявності розумної економічної причини (ділової мети) під час здійснення господарської діяльності. Оскільки господарська діяльність складається із сукупності господарських операцій платника податку (які $\epsilon$ формою здійснення господарської діяльності), то розумна економічна причина має бути наявною в кожній господарській операції. Лише в такому разі та чи інша операція може вважатися вчиненою в межах господарської діяльності платника податків. I лише за таких умов платник податків має право на врахування в податковому обліку наслідків відповідних господарських операцій.

Таким чином, лише господарські операції, здійснені за наявності розумних економічних причин (ділової мети), є такими, що вчинені в межах господарської діяльності < ..> Сутність доктрини ділової мети полягає в тому, що передбачені податковим законодавством податкові вигоди поширюються лише на операції, які мають розумну економічну причину. У вирішенні податкових спорів презюмується добросовісність платника податку і, відповідно, обгрунтованість отриманої ним податкової вигоди (тобто зменшення податкового зобов'язання)» [5].

3 відповідної правової позиції випливає декілька принципових положень. По-перше, наявність ділової мети повинна простежуватися в кожній господарській операції. Без цього (без ділової мети) такі операції платника податків не можуть трактуватися як такі, що були вчинені в межах його господарської діяльності. По-друге, судом було закріплено пряму кореляцію доктрини розумної економічної причини (ділової мети) 3 доктриною податкових вигод. Такого роду підхід зумовлюється тим, що судом було сформульовано позицію, у відповідності до якої тільки операції, здійснені за наявності ділової мети, можуть вважатися такими, що зумовлюють право на отримання податкових вигод. По-третє, суд сформував у рамках відповідної правової позиції презумпцію добросовісності платника податків.

Також потрібно звернути увагу на позицію, закріплену в Постанові Верховного Суду в складі колегії суддів Касаційного адміністративного суду від 02.10.2018 р. (справа № 822/844/16), де зазначалося таке: «Відповідність господарської операції діловій меті, про що може свідчити й економічна обгрунтованість витрат на ії здійснення, $\epsilon$ необхідною умовою для реалізації платником податків права на отримання податкових преференцій, оскільки їх встановлення законодавцем має на меті стимулювання ділової активності учасників торгівельного обороту, що у свою чергу передбачає здійснення господарських операцій, які $є$ об'єктом оподаткування, 3 метою досягнення економічного ефекту (ділової мети), а не тільки з метою отримання податкової вигоди. Відсутність економічної доцільності господарських операцій, окрім як здійснення їх з метою отримання податкової вигоди у вигляді витрат та/ або податкового кредиту, є підставою для зменшення в податковому обліку платника податків сум витрат та/або податкового кредиту. Завідома для платника податків відсутність розумної економічної причини щодо певних витрат під час здійснення господарської операції зазвичай виключає підстави для збільшення в податковому обліку витрат та/або податкового кредиту, оскільки таке в більшості своїй свідчить про відсутність ділової мети у такої господарської операції як притаманної риси господарської діяльності. Таким чином, право на формування податкових вигод виникає у платника податків за наявності сукупності обставин та підстав, однією з яких є ділова мета».

У рамках відповідної позиції знову ж таки було підкреслено взаємозумовлюючий характер доктрини ділової мети та доктрини податкових вигод. Крім цього, судом було запропоновано альтернативне означення податкових вигод - податкові преференції. При цьому суд дійшов висновку, що отримання платником податків податкових вигод у вигляді витрат (в аспекті податку на прибуток) або ж податкового кредиту (в аспекті ПДВ) не $є$ допустимим без наявності розумної економічної причини в операціях, які й зумовлюють такі вигоди. Важливо відмітити те, що суд зазначив у даному рішенні про завідому для платника 
податків відсутність розумної економічної причини операції. Як на практиці повинна встановлюватися така «завідомість», залишається незрозумілим. Безумовно, це може встановлюватися, виходячи із сукупності конкретних обставин у кожній окремо взятій справі. Проте, на наше переконання, якщо суд формулює тезу про «завідомість», то він і повинен конкретизувати ії прояви.

Розглянемо правову позицію, сформульовану в Постанові Верховного Суду в складі колегії суддів Касаційного адміністративного суду від 27.12.2018 р. (справа № 804/5343/14). Так, у відповідному рішенні зазначалося: «Відповідність господарської операції діловій меті, про що може свідчити і економічна обгрунтованість витрат на іiі здійснення, є необхідною умовою для реалізації платником податку права на податковий кредит. Це відповідає самому змісту вищенаведених норм ПК, які надають платнику податку право зменшити податкові зобов'язання на суму податку, сплаченого ним у зв'язку $з$ придбанням товарів (послуг) під час здійснення господарської діяльності. Встановлення законодавцем податкових преференцій має на меті стимулювання ділової активності учасників торгівельного обороту, що у свою чергу презюмує здійснення господарських операцій, які є об'єктом оподаткування, з метою досягнення економічного ефекту (ділової мети), а не тільки 3 метою отримання податкової вигоди. Відсутність економічної доцільності господарських операцій, окрім як здійснення їх 3 метою отримання податкової вигоди у вигляді податкового кредиту, $є$ підставою для зменшення в податковому обліку платника податку суми податкового кредиту. Завідома для платника податків відсутність розумної економічної причини щодо певних витрат під час здійснення господарської операції, як правило, виключає підстави для збільшення в податковому обліку витрат та/або податкового кредиту, оскільки таке в більшості своїй свідчить про відсутність ділової мети у такої господарської операції як притаманної риси господарської діяльності. Збитковість окремої господарської операції не $\epsilon$ беззаперечним свідченням відсутності ділової мети платника податків під час здійснення цієї операції, оскільки реалізація товару 3 певними збитками може бути викликана об'єктивними обставинами, як-то: зміна цін на ринку; необхідність його реалізації через загрозу псування; зміна курсу іноземних валют у випадку імпортних та/або експортних операцій тощо» [7].
У даному рішенні було згадано про зумовленість ділової мети економічним ефектом. Як ми знаємо, натепер через поняття «економічний ефект» законодавець пропонує визначати наявність розумної економічної причини (ділової мети). При цьому суд вірно зауважив, що збитковість окремої операції ще не може свідчити про відсутність ділової мети, оскільки така збитковість може бути зумовлена об'єктивними чинниками - поточною кон’юнктурою ринку.

Концептуально розгорнуті формулювання судової доктрини розумної економічної причини (ділової мети) були сформовані в Постанові Верховного Суду в складі колегії суддів Касаційного адміністративного суду від 23.04.2019 р. (справа № 804/6788/14). У відповідному рішенні зазначалося таке: «Отже, зміст поняття розумної економічної причини (ділової мети) передбачає обов'язкову спрямованість будь-якої операції платника на отримання позитивного економічного ефекту, тобто на приріст (збереження) активів платника (іхню вартість), а так само створення умов для такого приросту (збереження) в майбутньому. Водночас не обов'язково, аби економічний ефект спостерігався негайно після вчинення операції. Не виключено, що такий ефект настане в майбутньому, а також не виключено, що в результаті об' єктивних причин економічний ефект може не настати взагалі. Зокрема, операція може виявитись збитковою, і це є одним із варіантів нормального перебігу подій під час здійснення господарської діяльності. Проте із визначеного в Податковому кодексі України (у редакції, чинній на час виникнення спірних правовідносин) поняття ділової мети випливає, що обов'язково повинен бути намір платника податку отримати відповідний економічний ефект, тобто господарська операція принаймні теоретично (за умови досягнення поставлених завдань) має передбачати можливість приросту або збереження активів чи їхньої вартості. Якщо ж та чи інша операція не зумовлена розумними економічними причинами (позбавлена ділової мети), то такі операції не $\epsilon$ вчиненими в межах господарської діяльності, а отже, їхні наслідки не підлягають відображенню в податковому обліку. 3'ясування наміру платника податку на отримання економічного ефекту від господарської операції передбачає аналіз умов та обставин іiї здійснення. При цьому економічний ефект не повинен полягати виключно в зменшенні податкового навантаження на хоча б одного з учасників операції. Відповідно, економічний ефект відсутній в операціях, які призво- 
дять до збільшення задекларованих витрат платника та зменшують об'єкт його оподаткування без можливості отримання додаткового приросту активів чи збереження їхньої вартості. При цьому треба виходити з того, якою в тій чи іншій ситуації має бути поведінка добросовісного суб'єкта господарювання, що за звичайних умов ведення господарської діяльності зацікавлений у найбільшому скороченні своїх витрат. Відповідно, позбавлена розумної економічної причини операція, що збільшує витрати платника податку за наявності об'єктивної можливості до їх скорочення» [8].

У рамках відповідного рішення отримало свій концептуальний розвиток поняття «економічного ефекту». Як відмічає суд, економічний ефект є наявним тоді, коли операція спрямована на приріст (збереження) активів платника податків або ж сприяє створенню умов для такого приросту (збереження) у майбутньому. Тобто останні новели законодавця (положення Закону № 466) в аспекті нормативної концептуалізації розумної економічної причини (ділової мети) основувалися на судовій практиці. Таким чином, ми можемо зазначити про яскравий приклад «рецепції» законодавцем положень судових доктрин та їх перенесення в нормативну площину. Чи послідовно та цілісно було перенесено нормотворцем такі судові доктрини? Це вже питання.

Принаймні з положень Закону № 466 вбачається вибірковість запозичення судових доктрин. Так, нормотворцем було взято цілу низку положень правових позицій судів, які мають фіскально-орієнтований характер. Водночас положення судових доктрин, які спрямовані на забезпечення інтересів платника податків, зокрема в аспекті перешкоджання зловживанням із боку контролюючого органу, були проігноровані законодавцем. У даній правовій позиції також влучно сформульована теза, яка встановлює певного роду баланс у визначенні операцій, які можуть трактуватися як такі, що вчинені 3 діловою метою: господарська операція не має ділової мети, якщо вона призводить до виникнення витрат у платника податків, тоді як вона об'єктивно може призводити до їх скорочення.

Цікава правова позиція була сформульована в Постанові Верховного Суду в складі колегії суддів Касаційного адміністративного суду від 17.10.2019 p. (справа № 816/2270/16), де зазначалося таке: «Дійсно прибутковість кожної окремої операції не $є$ обов'язковою ознакою господарської діяльності, адже вона може включати й окремі збиткові операції, які, хоча й були спрямовані на одержання прибутку, однак з об'єктивних причин призвели до негативних фінансово-економічних наслідків. Натомість визначальною ознакою господарської діяльності $є$ наявність мети з отримання прибутку, а збитковість операції може бути зумовлена комерційним ризиком. Однак слід зауважити, що віднесення збиткових операцій до господарських можливе у випадках обгрунтування платником податку економічних причин чи ділової мети (зважаючи на ризики підприємницької діяльності) укладення угод за ціною, нижчою за виробничу собівартість» [9].

У відповідному рішенні суд наголосив на тому, що збитковість окремих господарських операцій ще не означає, що вони здійснені без ділової мети. Збитковий характер господарської діяльності може бути зумовлений об'єктивними економічними факторами. Однак обгрунтування об'єктивності таких збитків суд чомусь покладає саме на платника податків, що не можна назвати послідовним. Як ми знаємо, довести обгрунтованість своїх претензій в адміністративному судочинстві повинні контролюючі органи. Тобто саме владний суб'єкт повинен аргументувати відсутність у платника податків ділової мети.

Відносно котраверсійна позиція була висловлена в Постанові Верховного Суду в складі колегії суддів Касаційного адміністративного суду від 07.07.2020 р. (справа № 440/3633/19), де зазначалося: «У тому разі, якщо та чи інша операція не зумовлена розумними економічними причинами (позбавлена ділової мети), то такі операції не $\epsilon$ вчиненими в межах господарської діяльності, а тому їхні наслідки не можуть бути відображені в податковому обліку платника податків ... Збитковість від господарських операцій не свідчить про те, що такі операції не мають ділової мети або здійснені без наміру одержати економічний ефект, оскільки під час здійснення господарських операцій існує звичайний комерційний ризик не отримати дохід» [10].

Контраверсійність вищезазначеної позиції зумовлюється тим, що, з одного боку, суд відмічає про «розумність» економічних причин, які важко підтвердити за об'єктивної збитковості господарських операцій. При цьому, з іншого боку, суд говорить про те, що збитковість господарських операцій ще не свідчить про їх вчинення без наявності розумної економічної причини.

Висновки. Отже, аналізуючи вищенаведене, потрібно зазначити, що первинно доктрина розумної економічної причини (ділової мети) концептуально формувалася саме на рівні судо- 
вої практики. Така ситуація дозволяе говорити, що як етимологічно (за погодженням), так і змістовно концепція розумної економічної причини (ділової мети) є саме судовою доктриною. Що ж стосується нормативної формалізації відповідної доктрини, то вона має спорадичний характер та зорієнтована виключно в бік фіскалізації нор- мативного регулювання. Послідовність нормативної формалізації доктрини розумної економічної причини (ділової мети) є під питанням через своє змістовне наповнення (в аспекті повноти відображення) та помилки нормативного конструювання (пояснення оціночного поняття за посередництвом інших оціночних понять).

\section{Список літератури:}

1. Закон України «Про внесення змін до Податкового кодексу України щодо вдосконалення адміністрування податків, усунення технічних та логічних неузгодженостей у податковому законодавстві» від 16.01.2020 p. № 466-IX. URL: https://zakon.rada.gov.ua/laws/show/466-20\#n126

2. Кашанина Т.В. Оценочные понятия в советском праве : автореф. дисс. ... канд. юрид. наук : 12.00 .08 ; Свердлов. юрид. ин-т. Спб., 1974. 17 с.

3. Коломоєць Т.О., Лютіков П.С., Глухий О.Г. Принцип дії оціночних понять у вітчизняному податковому праві. URL: https://www.google.ru/url?sa $=\mathrm{t} \& \mathrm{rct}=\mathrm{j} \& \mathrm{q}=\& \mathrm{esrc}=\mathrm{s} \&$ source=web\&cd=\&ved= 2ahUKEwiJt bs0djqAhWytIsKHRH5A AQFjAAegQIAhAB\&url=http\%3 A\%2F\%2Firbis-nbuv.gov. ua $\% 2$ Fcgi-bin $\% 2$ Firbis_nbuv $\% 2 F c g i i r b i s$ 64.exe $\% 3 F C 21 \mathrm{COM} \% 3 \mathrm{D} 2 \% 26 \mathrm{I} 21 \mathrm{DBN} \% 3 \mathrm{DUJRN} \% 26 \mathrm{P} 21 \mathrm{DB}$ N\%3DUJRN\%26IMAGE_FILE_DOWNLOAD\%3D1\%26Image_file_name\%3DPDF\%2FFp_2014_3_6. pdf\&usg=AOvVaw1d1YurMMh7-xuwSJ2KLlw2

4. Податковий кодекс України в редакції від 01.07.2020 p. URL: https://zakon.rada.gov.ua/laws/ show/2755-17\#Text

5. Постанова Верховного Суду у складі колегії суддів Касаційного адміністративного суду від 06.06.2018 p. (справа № 804/7948/16). URL: http://reyestr.court.gov.ua/Review/74894233

6. Постанова Верховного Суду у складі колегії суддів Касаційного адміністративного суду від 02.10.2018 p. (справа № 822/844/16). URL: http://reyestr.court.gov.ua/Review/76905989

7. Постанова Верховного Суду у складі колегії суддів Касаційного адміністративного суду від 27.12.2018 p. (справа № 804/5343/14). URL: http://reyestr.court.gov.ua/Review/78991405

8. Постанова Верховного Суду у складі колегії суддів Касаційного адміністративного суду від 23.04.2019 p. (справа 804/6788/14). URL: http://reyestr.court.gov.ua/Review/81431145

9. Постанова Верховного Суду у складі колегії суддів Касаційного адміністративного суду від 17.10.2019 p. (справа № 816/2270/16). URL: http://reyestr.court.gov.ua/Review/85121367

10. Постанова Верховного Суду у складі колегії суддів Касаційного адміністративного суду від 07.07.2020 p. (справа № 440/3633/19). URL: http://reyestr.court.gov.ua/Review/90264331

\section{Smychok Ye.M. JUDICIAL DOCTRINE OF A MENTAL ECONOMIC REASON}

The author was be revealed the basics of the formation of judicial doctrine of mental economic reason (business purpose). Emphasis placed on normative approaches to the formulation of the concept of mental economic reason (business purpose) and forensic doctrinal concepts for determining its content. The studied doctrine of business purpose received its primary development in judicial practice. The interdependent nature of the doctrine of business purpose and the doctrine of tax benefits by judicial practice emphasized. Based on this, the characteristic features of the interdependence of the judicial doctrine of business purpose with other judicial doctrines were be identified and be described: the doctrine of tax benefits, the presumption of good faith of the taxpayer. As an example, the court proposed an alternative definition of tax benefits - tax preferences. In this case, the court concluded that the taxpayer's receipt of tax benefits in the form of costs (in terms of income tax) or tax credit (in terms of VAT) is not permissible without mental economic reason on the transactions that cause such benefits. In the article was the normative formulation of the concept of "economic effect" which has been subjected to constructive criticism. According to the court, the economic effect is available when the operation is aimed at increasing (maintaining) the assets of the taxpayer or contributes to the creation of conditions for such increase (preservation) in the future. Based on the study of the practice of courts of administrative jurisdiction was creating the fragmentary approach to the formulation of judicial doctrine of reasonable economic reason (business purpose). The judicial doctrine of mental economic reason needs quite logical normative elaboration. It is be established that the case law in this problem should be the basis for such regulatory modernization. In this case, the constructive interaction of the judiciary and the legislature is be traced. The judicial branch of power in terms of the formation of judicial doctrine of a mental economic reason has become a kind of pioneer.

Key words: tax law, doctrine of tax law, judicial doctrines, mental economic reason, business purpose, economic effect, judicial practice, tax benefit. 